\title{
Teachers' Perceptions of Principals' ICT Leadership
}

\author{
Ann-Louise Petersen \\ University West, Sweden
}

\begin{abstract}
This article focuses on the leadership used by the principal in a collaborative ICT project. The case study chosen was a school project conducted within the NCCE project (Nordic Cross Country Education). The EU funded project ran for three years in grades 5-9 in Sweden, Denmark and Norway. The goal of the project was to develop cross-border education models between the national education systems in the three countries. The project was based on virtual communication using digital technology. The study focuses on how the Swedish teachers from two schools involved in the NCCE project experienced the leadership of the principals in ICT related matters. A qualitative method was used by interviewing the teachers in order to inquire about what kind of support they had received from the school leadership on pedagogical issues, technical equipment and ICT competence. The ICT leadership was analyzed by Dexter's three basic features: setting direction, developing people and making the organization work. The result showed two kinds of leadership. The first one resembled a distributed leadership, where the principal worked closely with teachers and ICT managers, almost like being one of the team. The second one resembled more a formal leadership where principals had a positive attitude towards ICT development but did not participate personally in the project work.
\end{abstract}

Keywords: ICT integration; ICT leadership; Distributed leadership; School development

\section{Introduction}

The principal's role as an educational leader is becoming increasingly important. The school leadership has developed from merely an administrative one to one that includes an educational leadership (Berg, 2011; Hallerström 2006; Höög \& Johansson, 2011; Larsson \& Löwstedt, 2010). The principal has a key role for pupils' learning by organizing the conditions for teaching as well as the working climate (Elmore, 2008; Hallinger \& Heck, 1998; Hopkins, 2008; Pont, Nusche \& Moorman, 2009). The pedagogical role entails stimulating teachers in their work and having responsibility for their professional development so that students receive the education that enables them to reach the goals of the national curriculum (Skolverket, 2011). This means that the principal is responsible for the development of local curricula as well as for the provision of study material and technical equipment. Furthermore, the principal is accountable for educational development and for creating opportunities for teachers to develop their professional skills. This article focuses on the principal's educational role in classes participating in a school project with a focus on $\mathrm{ICT}^{1}$, known as the NCCE project (Nordic Cross Country Education). In this project, the principal was a key figure by providing

\footnotetext{
${ }^{1}$ Computer-use in the end of the twentieth century put emphasis on the fact that information could be reached by technology, IT (information technology). Later more focus has been put on communication, and communication has therefore been added to the term, resulting in ICT (information and communication technology).
} 
the conditions for the participation of teachers and classes. For example, the principal determined the amount of time teachers were allowed to allocate to the project in order to plan lessons and communicate with teachers from the other schools. Furthermore, he or she also decided what technical equipment and technical infrastructure that was available for the project. The above-mentioned tasks of the principals in the NCCE project were not merely rational and technical in nature. One of the crucial tasks was the principal's personal engagement in the project. A school project without personal support or commitment from the principal has been shown to have a lower chance of succeeding (Petersen, 2010; Petersen, 2012; Petersen, 2013; Stedøy, 2006). In this study, the leadership of principals in ICT related matters in two different schools were evaluated and compared based on the experiences of teachers involved in the NCCE project. The aim of the study was to take the teachers' point of view in order to acquire an understanding of the expectations on principals in their role as educational leaders in a school project based on virtual communication.

\section{The Importance of the Principal for ICT Development}

The principal has a prominent role when it comes to creating a collaborative working culture together with teachers and students, in addition to providing the right conditions for pedagogical development. According to Grosin (2003, pp. 143-144), successful schools are characterized by "a clear and democratic but strong leadership from the principal, targeting in particular the school's learning goals; a pedagogical/didactic leadership from the principal; the dedication of the principal and teachers". Grosin refers to the pedagogical and social climate "PESOK" that provides a complex image of the values and norms of the school management and teaching staff, which are reflected in the everyday conduct at the school. The PESOK concept includes the school's culture as well as structural factors. The culture determines, through a dynamic interplay, the structure of the school, that is to say the interaction between the principal, teachers and students. A number of researchers concur with the importance of the principal's ability to interact and communicate with the school's teachers (Augustinsson \& Brynolf, 2009; Berg, 2003; Björkman, 2008; Ekholm et al., 2000; Höög, Johansson \& Olofsson, 2005) also highlight the importance of supporting the teachers' own development. Additionally, Ärlestig (2011), who studied communication processes, emphasizes the importance of a multidimensional communication from the principal in which pedagogical issues related to teaching methods and results play an important role. Björkman (2011, p. 140) studied on principals in different schools from the perspective of school improvement processes. He pointed out two kinds of leadership: a successful one, "the involvement leadership", and a less successful one, "the separating leadership". The involvement leadership entailed the principal being convinced that everyone could contribute to school development. It was characterized by an openness regarding what was going on at the school as well as a tolerance for differing views in the discussions about educational matters. The principal was often present in the daily classroom work, active in the regular pedagogical meetings and gave the teachers feedback on a regular basis. The separating leadership on the other hand entailed the principal keeping to his/her formal position as an executive while the teachers were responsible for their respective subjects and the pedagogical development. However, the teachers had more freedom within their subjects. The principal participated in more organizational meetings, but not in the pedagogical meetings that the teachers organized themselves.

The use of computers in schools has brought a new approach to teaching that places new demands on teachers as well as the school management and the organization of activities. 
Schools that invested in ICT development with a team-based organizational structure have been more successful than schools characterized by formal organizational structures or autonomous individuals. Namely, the latter were not in the same way able to coordinate and disseminate teachers' experience and skills (Erstad, 2011; Larsson, 2004; Larsson \& Löwstedt, 2010). Other research shows that the most successful ICT development efforts were carried out in schools whose principals were geared towards ICT in terms of their attitudes and behavior. The critical factors that determine whether teachers work with ICT seem to be the principal's support for the pedagogical development of the teachers, available technical support and the provision of technical infrastructure (Law, 2008; Ottestad, 2013). ICT integration is also dependent on the pedagogical beliefs of the teachers; beliefs that ICT would make the teaching more effective (Ertmar \& Ottenbreit-Leftwich, 2010). Consequently, a crucial step towards ICT integration is to formulate a strategic plan that sets clear goals and defines the means to understand these goals (Bryderup \& Kowalski, 2002). The introduction of ICT based work implies that the teacher, on the basis of the educational objectives, must combine the subject with the pedagogical approach and technology so as to facilitate the learning. Harris, Mishra, and Koehler (2009) illustrate these elements in the so-called "TPACKmodel" (Technological Pedagogical Content Knowledge), a teaching model that emphasizes the importance of integration between pedagogy, technology and subject content. However, it turns out that the model has been difficult to implement in practice. In studies on teaching in a one-to-one environment in a Swedish primary school, the teachers, in their eagerness to introduce the new computer technology, proved that technology easily becomes the end in itself as opposed to a tool that facilitates the learning process (Petersen \& Bunting, 2012). Instead of an "education pull" one observed a "technical pull" (p. 261), i.e. instead of focusing on the thematic objectives when selecting the appropriate technology, teachers focused on the technologies and programs that were interesting in the eyes of the students. In other words, the technical content was given priority as opposed to the subject content and the pedagogy.

Stuart, Mills, and Remus (2009) conclude in their study that the principal's knowledge of ICT is correlated with the principal's willingness to push for ICT development. However, they did not observe a similar relationship with the principal's personal use of ICT. Hu, Clark and Ma (2003) reached comparable results when it came to teachers; that the teachers' computer literacy was important for embracing new technology. Dexter (2008) argues that a school leader must have both ICT knowledge and be able to organize school activities. The researcher highlights three basic features that should characterize school leadership for developing ICT, to articulate visions and goals "setting direction", help develop the teaching staff professionally "developing people", and organize activities so that development takes place "making the organization work" (p. 543). Goals and visions can be formulated at different levels, but in order to get the maximum impact and scope, they should be initiated at a higher level, for example at the regional or municipal level. These policies can then be concretized at school level and adapted to students' school performance, says Dexter. At the individual school one must thus develop goals and visions for the subject matters, technical and pedagogical approaches for the topics, as well as goals for teachers' skills. This is related to the second basic function, developing the staff. The task of the ICT manager will be to provide the staff with the necessary ICT skills for an ICT integrated approach in the creation of a learning environment. This calls for skill enhancement, both in the technical and pedagogical field, but also for access to technical equipment and continuous support. According to Dexter, a knowledge based ICT learning environment should focus on developing teachers' deeper understanding of how to integrate ICT in course planning and evaluation, as well as on how ICT helps to enhance learning. Achieving such an environment requires continuous learning and an interaction between 
teachers for a longer period of time where they are trained to develop an understanding of the opportunities and the flexibility that ICT tools offer. The third basic function regards the organization of school activities and the provision of the resources and technical infrastructure required. In order to attain a successful ICT leadership, knowledge is thus needed from different fields: from an administrative and financial point of view, the subject content and pedagogy, and the technical aspects. In other words, a successful ICT leadership should be composed of individuals with different competencies. Bennett (2008) uses the concept of a "distributed leadership" (p. 603), meaning that a group or a network of interacting individuals with different expertise should share the ICT leadership. The group could for example be comprised of the principal, the ICT manager and teacher representatives. The school leadership can from this perspective best be understood in terms of the issues and challenges that must be resolved and less in terms of each individual's formal role. This implies that the group of individuals that make up the ICT leadership together interact and employ different tools, structures, and resources in order to develop an ICT environment at the school.

\section{Methodology}

The aim of the study was to enquire into how the teachers experienced the pedagogical leadership of the principals in the school project NCCE, an ICT project based on virtual communication. NCCE was a collaborative project between Swedish, Norwegian and Danish schools in grades 5-9. In total there were 16-paired classes coming from 5 schools in Sweden, 4 in Norway and 3 in Denmark. The project ran over three years from 2011-2014 and was financed by EU funds. In Sweden, six schools initially participated in the project, but after two years only five schools remained. Running a project differs in several ways from the everyday work at school. A project is usually described as a temporary activity, carried out with clearly delimited resources aimed at attaining a pre-defined goal. There are furthermore different kinds of projects, such as for example goal-oriented or goal-seeking projects (Hallin \& Karrbom Gustavsson, 2012). NCCE was largely a goal-oriented project, with a main goal to develop cross-border education models to create consensus between the national education systems in the three countries. It was also a goal to develop models for education in networks, and to spread these within the respective schools. However, in this study the relative small amount of teachers and classes involved at the respective schools could make the dissemination difficult to implement. There is a risk to create "islands" and not share the knowledge and experiences of the project to the rest of the school (Grensjö, 2002).

The NCCE-classes collaborated within four subjects; native language, science, mathematics and social studies/history. Communication between students was conducted through digital technologies and the students used their respective native languages when communicating in order to get familiar with the neighboring Nordic languages. A number of researchers have followed and studied the project based on an action research approach (Denscombe, 2009; Friedman, 2001), a methodology based on research in practice as opposed to in theory. The role of the researcher was to, in this particular case, discuss, clarify and problematize circumstances that seemed relevant to develop in the project together with the practitioner. Researchers with different perspectives were involved in the project; from a classroom perspective, from an ICT perspective and from a school leadership perspective. This author has participated as a researcher focusing specifically on the school leaders.

The present study did not focus on the cross border collaboration or the teaching sequences done between the schools in the three countries. Instead, this study was limited to examining 
the leadership of the principals in two of the five schools in Sweden after participating in the project for 1.5 years. For that purpose, the teachers' perceptions of leadership have been explored. The two schools were selected for the study because they seemed to do quite well in the cross border work, but they differed from each other in terms of their student population. School 1 was a fairly new and multicultural school, and the results of the national tests showed low target achievements. The school was of the type F-9 (preschool through grade 9) and had two principals; one of them had had a long experience as a principal while the other was hired only a few years earlier. The school was located in the outskirts of a medium-sized Swedish municipality in an area with a large proportion of pupils with a mother tongue other than Swedish. The school took part in the NCCE project with a $6^{\text {th }}$ grade class in mathematics, which had two teachers. School 2 on the other hand was fairly old, the socio-economic background of the pupils was quite high, most pupils had Swedish as their mother tongue and they showed significantly higher achievements on the national tests (Skolverket, 2013). School 2 was a 6-9 school (grade 6 through 9) and also had two principals, both of which were recently appointed. One of the principals had previously been the ICT manager at the school and the other was hired just 9 months earlier, but had previously had a long period of employment as the principal of another school. School 2 was located in a suburb municipality of a larger city. The school participated in the NCCE project with an $8^{\text {th }}$ grade class in native language with one teacher and a $9^{\text {th }}$ grade class in science with another teacher. In both schools, students each had a computer provided by the school.

A qualitative method was used to get an understanding of the principals' leadership from the teachers' perspective (Kvale, 2008). The basis of this study was to interview the participating teachers from the two schools during the fourth semester of the project. Both teachers from school 1 taught mathematics while the teachers from school 2 taught science and native language (Swedish) respectively. All of them were female and had had at least 10 years of teaching experience. The interviews were conducted in pairs at each school for about 45-50 minutes and they were audio recorded. The prepared questions were the starting point for the interviews, but the teachers were also encouraged to speak freely. As in all interview-based research, there is the potential danger of respondents answering what they believe is expected from them or that the replies are biased for other reasons. In this particular case, this potential bias could not be ignored, especially since the author had followed the project since it started. However, she had not had any previous direct contact with the teachers. It was nevertheless important to be aware of this position when carrying out the interviews and it calls for a careful interpretation of the replies as well as an awareness of one's own prejudices of the project's development (Fejes \& Thornberg, 2009). Silverman (2006) points out the researcher's responsibility to the persons involved in the study with respect to their confidentiality. The interviewed teachers were informed about the ethical issues faced by participation in the study. In this case, the teachers were expected to talk about their superiors, which may be sensitive and could therefore potentially bias the answers. However, when asking the teachers to participate they did not show any hesitation to do so. Also the principals were informed about the study and agreed to it. To avoid any personal conversations or topics outside the questions at hand the researcher tried as much as possible to stick to issues related to the NCCE project. The fact that the researcher already was familiar with the principals in question helped to assess the credibility of the respondents' answers. Some circumstances of the project were already known as they had been discussed in the recurrent principals meetings, in which this author participated. This facilitated the understanding when evaluating the interviewees' responses and strengthened the validity of the results. 
In order to acquire an understanding of how the teachers experienced the principal's leadership in the ICT-driven work in the NCCE project, this study investigated the visions and goals of the project, what support teachers had received from their principals but also what support they lacked and would have liked to have. In the interviews, the following questions were asked based on Dexter's (2008) three basic functions: "setting direction", "developing people" and "making the organization work".

1. How do you perceive the principal's vision of the use of ICT in the school?

2. What support is available to you from the principal concerning your use of ICT in teaching?

3. What support would you have liked to have?

4. How does the principal support/lead your skills enhancement in order to integrate ICT in your teaching?

5. How does the principal stimulate collaboration among teachers to develop the use of ICT overall?

6. The principal's role consists of a number of tasks and responsibilities. The educational leadership is one of them. Please describe how you experience the principal's educational leadership.

The audio-recorded interviews of the teachers were transcribed and categorized according to the three functions of an ICT leadership as defined by Dexter (2008). Hereinafter follows a presentation that will illustrate two types of leadership. Direct quotations are marked with citation signs.

\section{Results}

The first area of inquiry regards whether the teachers perceived that the principals and/or school administration had set a vision or a goal for the development of ICT in the education. The teachers in school 1 believed that the principals had great visions for the incorporation of computer use at the school. They expected future developments of a completely digital (paperless) school. The teachers mentioned that the principals had shown a willingness to prepare students for life outside of school, thus insisting on integrating ICT in the education. The teachers in school 2 communicated quite different accounts. According to them, the principals at school 2 had been positive towards the use of computers and the developments taking place, but had not expressed any particular visions for the use of ICT.

Also when it came to the teachers' perceptions of the principals' support and stimulation, the two leaderships seemed to differ from one another, although the principals in both schools were considered to be supportive of the teachers in their use of ICT in the NCCE project. The teachers in school 1 experienced that they had received considerable support from their principals. They had arranged it so that the municipality ICT manager regularly organized workshops where various kinds of software was presented. The principals were considered to be happy to help if needed: "If we ask for help, it is given to us"; "they try to stimulate us". The principals themselves participated in trainings in order to learn more about ICT. The teachers in school 1 perceived their principals as role models when it came to ICT use: "They continuously educate themselves". The problem, according to the teachers, was that their amount of working hours was not sufficient for everything they were encouraged to and would 
have liked to do: "The problem is that we do not have time to develop programs and practice the use of computers. There is also a lack of time when it comes to trying out different tools with the students. We usually have to employ the technology without having had the time to develop the pedagogical aspects. We never have time to go in-depth". Besides wanting more time for ICT development, the teachers wished that the principals had been more involved in the actual teaching. During the first year of the NCCE project, the cooperation between the matching classes did not work so well which made the principals involve themselves in the teaching. One year later, the collaboration and teaching together with the other countries ran more smoothly and the principals were thus no longer involved in the teaching: "The school leaders have been more absent this year in the NCCE project and I do not think that they are aware of what we are doing". The teachers felt that they were allocated too few hours for the NCCE project in order to plan the work together with the other teachers as well as for the actual implementation of the project: "We must do everything that other teachers at the school do in addition to the collaboration with teachers in the NCCE project, which has been stressful. We would need additional hours for the technological development for the NCCE project. The time spent uploading assignments on Wikispaces (a collaborative website where users can contribute to a joint work) must be taken from other important course elements such as planning math exercises".

The teachers in school 2 stated that they felt supported by the principals when it came to ICT development. The principals were perceived as willing to support the teachers in the use of computers and were keen to enable teachers to take advantage of new methods and of ICTsupported programs in particular. At the same time, the teachers experienced that the principals were not able to focus as much on ICT due to a large amount of other tasks: "If there is something new, we always have a chance to learn, or at least the principals refer to it. So it feels like they want us to make use of ICT in the education". ICT skills development was carried out primarily at inspiration and study days organized by the municipality. Overall, the principals were said to encourage teachers to help each other if they try out something new, but "we do not have enough time to collaborate". In the NCCE project however, teachers felt that they had been allocated enough time to plan and implement teaching that they were content with. The principals had not been involved in the practical NCCE work, although they were reported to have been interested in the project as a whole and to continuously ask how it proceeded. One principal sometimes helped solve technical problems. When asked what the principals' educational leadership looked like, teachers were hesitant to reply, partly because the principals were relatively new and partly because they themselves felt responsible for the educational leadership: "It is mainly we who are in charge of the educational leadership". The teachers did not seem to demand that the principals guided their work. Instead they preferred to plan the courses based on the national curriculum and decide for themselves how to design the teaching: "... hence we do not want the principals to interfere. We do not want to be controlled. It's a Catch 22; on the one hand, we would like to have some guidance, but on the other hand we do not allow anyone to comment on how we choose to conduct our teaching".

Since the NCCE collaboration relied on virtual communication, it was important that students had access to the technical equipment, that the computers worked and that the technical infrastructure had sufficient capacity. Here, the teachers at the two schools differed in terms of their experiences. School 1 was reported to have computers that worked while the teachers in school 2 indicated that they had had major technical problems: "We have experienced huge problems with the computers. Half of the touchpads have been poor". Because of this, lessons had to be rescheduled: "It went so far that the students did not think it was worthwhile to bring their computers to school. We always have to have a combination of paper, pencils and computers", the teachers said. 
The teachers at both schools said that they had scheduled various meetings. School 1 had a weekly joint conference led by the principals where pedagogical issues were discussed and where the teachers displayed what digital tools they recently had used. They also had a "school development team" at the school where participation was voluntary from the teachers. Here, various educational topics and ideas were discussed that could develop the teaching at the school. During the first year of the NCCE project, the principals conducted a dialogue on a regular basis with the teachers. They also participated in and supported the actual teaching. More recently, teachers had become accustomed to the NCCE work and it was not as frequent as before that principals attended the NCCE meetings. The teachers at school 2 stated that they had three kinds of meetings: "workplace meeting, subject meetings and team meetings". Workplace meetings were reported to be chaired by the principal whilst the teachers led the other meetings. The teachers argued that because the principals did not participate in the purely educational meetings it was mainly the teachers who were in charge of pedagogical issues. Hence, there were no meetings scheduled specifically for NCCE. The two NCCE-teachers of the school had meetings of their own when needed. The principals were informed about the project now and then when they met at other meetings or incidentally during the school day. However, the teachers admitted that the principals had shown keen interest in educational issues. As an example the principals were said to raise educational issues on occasion during staff appraisals.

\section{Discussion}

Dexter (2008) argues that school leadership that promotes the development of ICT in education should focus on collaboration and ensuring the functioning of activities rather than on preserving formal roles. First and foremost, the leadership should be organized like a team made up of people with different competencies. This team-based structure comprising a wide range of expertise should promote the usage of computers as well as a variety of subject content, pedagogical practices, and technological and management issues. Dexter therefore proposes to focus on three functions in order to develop an educational ICT leadership, namely to formulate visions and objectives for the use of ICT "setting direction", to enable professional development for the teaching staff "developing people" and to provide the school, teachers and students with the necessary resources "making the organization work".

Both schools 1 and 2 worked according to the interviewees in a targeted manner towards fulfilling the national targets and towards an increased use of ICT. The difference was that school 1 had formulated its own vision on ICT use that the teachers reproduced during the interview. According to Ertmar and Ottenbreit-Leftwich (2010), a vision creates an image and expectations of what the ICT use should lead to and it influences the mind-set of the teachers. It could make them believe that ICT improves the teaching, thereby positively affecting their motivation. This is also in line with schools being encouraged to emphasize their own educational visions and goals according to the National Agency for Education (Skolverket, 2011). In school 2, the lack of a clear vision on ICT could possibly be explained by the relatively recent appointment of both principals.

The principals of both schools 1 and 2 were keen to make the teachers increase their computer usage. This requires an organization where time is allocated to professional development in order for the teachers to develop the required technical competence. Schibeci et al. (2008) highlight time as a critical factor for change to take place. Teachers from both schools were 
dissatisfied with the lack of time within normal working hours available in order to learn new software and test new digital tools. The teachers in school 2 would have appreciated more teacher meetings on ICT usage and demanded increased ICT knowledge and sharing of ideas and advice. The teachers at school 1 had already acquired a substantial skills set thanks to their weekly meetings, but they would have liked to have additional time in order to test and implement the newly found skills and ideas in their teaching. Consequently, it can be concluded that the occurrence of organized meetings on ICT is a critical factor that the management should adopt when targeting an ICT adapted education. Another critical factor is the technical support and functioning infrastructure (Ottestad, 2013; Law, 2008). Teachers at school 2 expressed in the interview that non-functioning computers not only created dissatisfaction and frustration among students and teachers. An additional consequence was that the computers were left unused and the teachers had to work longer hours in order to plan lessons with multiple working methods.

An ICT leadership entails the principal working continuously alongside teachers and ICT managers to develop teaching methods to improve the course design and to increase student participation and motivation (Dexter, 2008). This requires a kind of collective leadership where the principal interacts with other educators and where they together, each with their individual expertise, contribute to the development of ICT operations. Bennett (2008) uses the concept of distributed leadership. In contrast to a traditional leadership that follows a hierarchical structure based on formal rules, the focus here is on encouraging collaboration and sharing of expertise. In the foreground are problem solving and the joint development of the school's ICT operations. In the interviews with the teachers in the two schools, two types of leadership were portrayed. One leadership (school 1) can in some respects be defined as an expanded leadership or in Bennett's term: a distributed leadership. The principals attempted to approach the practical teaching activities. They furthermore took part in weekly meetings where computer usage was discussed, and the principals were involved operationally in the teaching within the NCCE project when needed. They were reported to have made an effort to train themselves on the topic of ICT and had informed teachers what they had learned at regular meetings. Hence, they interacted with the educators and pushed for ICT development by being personally committed to increasing ICT knowledge. One could also call it an integrated leadership, where the principal interacts with teachers and ICT managers. In the integrated leadership, the transfer of skills is reciprocal; principals, teachers and ICT managers all learn from each other. An integrated leadership entails seeing the benefits of collaboration, where individuals with different skills help each other to solve problems and develop school activities without an underlying framework of strict control (Bennett, 2008).

In school 2, the principals' leadership is more distant from the actual teaching. The principals were keen on enabling the teachers to develop their ICT skills, and encouraged the teachers in the NCCE project, though not by personally participating in the computer usage. Unlike in school 1, the principals in school 2 allocated a generous amount of time for teachers to implement the project. On the other hand, they did not participate in the discussions or planning of cross border teaching. This was a natural consequence from the fact that the teachers at the school did not demand collective interaction or an extended leadership. The teachers expressed with certainty that they did not want principals interfering in the actual teaching: "We do not want to be controlled", they argued with one voice: "A catch-22 "; on the one hand the teachers did not wish to be controlled but on the other hand they asked for support from the principals when it suited them. The teachers seemed to be afraid to lose their autonomy in their role as teachers. Hence, one could observe that both teachers and principals acted based on their respective traditional and formal roles. From the perspective of 
school development, Björkman (2011) defines two kinds of leadership; a successful one or "an involvement leadership" and a less successful one or "a separating leadership". The leadership of school 1 was portrayed in line with an involvement leadership and school 2 more as a separating leadership. Consequently, school 1 should have greater potential for school improvement when it comes to ICT-use.

A school project without personal support or commitment from the principals has been shown to have a lower chance of succeeding (Petersen, 2010; Petersen, 2012; Petersen, 2013; Stedøy, 2006). Therefore, it is important that teachers feel seen and appreciated from the school management, but also that teachers and school leaders together set up clear goals for the project in order to define expectations on the various roles as well as on the outcome of the project. In both schools, the teachers felt acknowledged and acclaimed by their respective principals in the NCCE project. Although school 2 would appear to have had a less integrated leadership than school 1 , teachers testified to the communication between principals and teachers. This could be one possible explanation for why the teachers in both schools showed dedication and joy in their work with the project. The pedagogical and social climate, the school culture, provides a complex image of values and norms that have developed over time (Grosin, 2003). Differences in school culture may explain the divergence in terms of leadership between school 1 and school 2. School 1 was unlike school 2 located in a multi-ethnic community, where most of the students had another mother tongue than Swedish and on average they performed poorly on the national tests. Against this background, the principals of the two schools were facing different challenges and had to prioritize different educational issues. At school 1, probably teaching, teaching methods and subject didactics were highprioritized tasks for the leaders, who aimed to support the teachers in their efforts to raise the academic achievements of the students. Consequently, one could hypothesize that the principals were more used to work in an integrated manner with the teachers and other categories of staff. At school 2, the principals perhaps faced other problems, not so closely related to teaching as in school 1 . The teachers handled education and they did not request any involvement from the principals. The more distant leadership thus seemed to work well for both principals and teachers.

A number of researchers have concluded that a successful leadership within the school in general should be based on interaction. There should be a strong communication between the principal and teachers, where the principal supports teachers in their educational development, and offers resources for professional development (Augustinsson \& Brynolf, 2009; Björkman, 2008; Ekholm et al., 2000; Höög et al., 2005; Ärlestig, 2011). In an ICT leadership, these factors are even more important because of the need for specific skill requirements and the functioning of technical infrastructure. If the interaction between the principal, teachers and ICT managers fails, the ICT development risks coming to a halt. All agents are dependent on each other's skills, experiences and resource responsibility in order to develop the ICT activities at the school. To support such interaction, a team-based organizational structure will be important in contrast to a traditional formal structure or autonomous individuals (Erstad, 2011; Larsson, 2004; Larsson \& Löwkvist, 2010).

\section{Conclusion}

Integrating ICT in education is a complicated and multi-faceted process. Effective leadership is one significant predictor of successful ICT use by teachers and students. Dexter (2008) highlights three basic features that should characterize school leadership: "setting direction", 
"developing people" and "making the organization work". These features require collaboration between all professionals at the school and shared pedagogical beliefs that ICT would make the teaching more effective with reference to Ertmer and Otterbreit-Leftwich (2010). In order to address each of these factors in an integrated manner, teaching should be seen as a collective task, where the principal together with teachers and ICT manager are active in organizing a continuing communication for building ICT competence.

In this article, the ICT leadership of the principal is viewed from a teacher perspective. When interviewing the teachers from two schools participating in a school project, two types of leadership have emerged. One type can be defined as a distributed leadership (Bennett, 2008), where the principals, teachers and ICT managers worked together in a team structure. The leadership was not focused on formal roles but rather on the activities that needed to be carried out as well as on the sharing of knowledge. The second type of leadership was more formal and distant with regards to the actual teaching and ICT development, but the principals nevertheless supported and encouraged the teachers in their work. In this second school, the teachers preferred not to be closely managed by the principals as they looked upon teaching as their exclusive task, a perception in line with a more traditional school culture.

The NCCE project has fostered an integrated leadership with an increased demand on the principal to be involved in teaching activities. A project can be defined as a temporary activity, conducted with delimited resources aimed to achieve a certain goal (Hallin \& Karrbom Gustavsson, 2012). The NCCE project was not delimited to the classroom or to the individual school. The cross border communication made it dependent on digital technology, computer literacy and interpersonal skills. As a consequence, organizational decisions on financial, pedagogical and technological matters had to be made based on the needs and inputs from people involved in the project. In the NCCE project, the principal had a shared responsibility together with the other schools to implement the project in a successful manner. This made it even more important for the principals to get involved in the teaching activities.

From research we know that school projects where only a few classes and teachers are involved, such as the NCCE project at both schools, are at risk to create "islands" and therefore fail to contribute to the development to the rest of school (Grensjö, 2002). However, an actively involved principal creates legitimacy and gives the project more weight, which should improve the project's dissemination within the school. Therefore, an integrated or an inclusive school leadership may reduce the risk of developing islands. In an integrated leadership the principal is an organizer and an inspirer, involved in different school activities. As Björkman (2008, p. 144) puts it "an inclusive leadership opens up for teamwork, to be the hub in what's going on at the school, and for participating in the daily work across subject boundaries".

\section{References}

Augustinsson, S. \& Brynolf, M. (2009). Rektors ledarskap, komplexitet och förändring. Lund: Studentlitteratur.

Bennett, N. (2008). Distributed Leadership and IT. In Joke Voogt and Gerald Knezek (Eds.) International handbook of information technology in primary and secondary education. New York Springer.

Berg, G. (2003). Att förstå skolan: En teori om skolan som institution och skolan som organisation. Lund: Studentlitteratur. 
Berg, G. (2011). Skolledarskap och skolans frirum. Lund: Studentlitteratur.

Björkman, C. (2008). Internal capacities for school improvement: Principal's views in Swedish secondary schools. Umeå: Pedagogiska institutionen, Umeå Universitet.

Björkman, C. (2011). Skolans ledarskap som intern förbättringskapacitet. In J. Höög \& O. Johansson (Eds.) Struktur, kultur och ledarskap. Lund: Studentlitteratur.

Bryderup, I.M. \& Kowalski, K. (2002). The role of the local authories in the integration of ICT in learning. Journal of Computer-Assisted Learning, 18, 470-479.

Denscomb, M. (2009). Forskningshandboken för småskaliga projekt inom samhällsvetenskaperna. Lund: Studentlitteratur.

Dexter, S. (2008). Leadership for IT in Schools. . In Joke Voogt and Gerald Knezek (Eds.) International handbook of information technology in primary and secondary education. New York: Springer.

Ekholm, M., Blossing, U., Kåräng, G., Lindvall, K., \& Scherp, H.Å. (2000). Forskning om rektor en forskningsöversikt. Stockholm: Skolverket.

Elmore, R. (2008). Leadership as the practice of improvement. Improving school leadership, Volume 2: Case studies on system leadership. OECD publication. Available at: http://www.teindia.nic.in/Files/Improving_sch_Leadership/Improving_Sch_Leadership_ OECD-Vol-2.pdf

Erstad, O. (2011). Digitalt kompetanse i skoler. In Ola Erstad \& Trond Eiliv Hauge (Eds.) Skoleutvikling og digitalemedier: Kompleksitet, mangfold, ekspansiv läring. Oslo: Gyldendal Akademisk.

Ertmer, P. \& Ottenbreit-Leftwich, A. (2010). Teacher technology change: How knowledge, confidence, beliefs, and culture intersect. Journal of Research on Technology in Education, 42(3), 255-284.

Fejes, A. \& Thornberg, R. (2009). Handbok i kvalitativ analys. Stockholm: Liber.

Friedman, V. (2001). Action Science: Creating Communities of Inquiry in Communities of Practice. I P. Reason och H. Bradbury (Eds.) Handbook of action research. London: Sage.

Grensjö, B. (2002). Erfarenheter sprids - Kunskaper används? Enkätstudie bland KK-stödda mindre skolutvecklingsprojekt. Pedagogiska Rapporter, Nr 67. Umeå: Pedagogiska Institutionen, Umeå Universitetet.

Grosin, L. (2003). Forskning om framgångsrika skolor som grund för skolutveckling. In G. Berg \& H-G. Scherp (Eds.) Skolutvecklingens många ansikten. Stockholm: Myndigheten för skolutveckling.

Hallerström, H. (2006). Rektors Normer i ledarskapet för skolutveckling. Lunds universitet: Sociologiska institutionen.

Hallin, A \& Karrbom Gustafsson, T. (2012). Projektledning. Malmö: Liber.

Hallinger, P. \& Heck, R. (1998). Exploring the principal's role in school effectiveness. School Effectiveness and School Improvement, 9(2), 157-191.

Harris, J., Mishra, P. \& Koehler, M. (2009). teachers' technological pedagogical content knowledge and learning activity types: Curriculum-based technology integration reframed. Journal of Research on Technology in Education, 41(4), 393-416. 
Hopkins, D. (2008). Realizing the potential of system leadership. In B. Pont, D. Nusche, D. Hopkins (Eds.) Improving school leadership, Volume 2: Case studies on system leadership. OECD publication. Available at: http://www.teindia.nic.in/Files/Improving_ sch_Leadership/Improving_Sch_Leadership_OECD-Vol-2.pd.

Hu, P.J., Clark, T.H. \& Ma, W.M. (2003). Examining technology acceptance for school teachers: A longitudinal study. Information and Management, 41(2), 227-241.

Höög J. \& Johansson, O. (2011). Struktur, kultur, ledarskap - Ett projekt och dess resultat. In J. Höög \& O. Johansson (Eds.) Struktur, kultur och ledarskap. Lund: Studentlitteratur.

Höög, O., Johansson O., \& Olofsson, A. (2005). Successful principalship: The Swedish case. The Journal of Educational Administration, 43(6), 595-606.

Kvale, S. (2008) Den kvalitativa forskningsintervjun. Lund: Studentlitteratur.

Larsson, P. (2004). Förändringens villkor. En studie om organisatoriskt lärande och förändring inom skolan. Avhandling, Stockholm: Handelshögskolan.

Larsson, P. \& Löwstedt, J. (2010). Strategier och Förändringsmyter, ett organisationsperspektiv på skolutveckling och lärares arbete. Lund: Studentlitteratur.

Law, N. (2008). In search of explanations. In N. Law, W.J. Pelgrum \& T. Plomp (Eds.), Pedagogy and ICT use in schools around the world: Findings from IEA SITES 2006 study. Dordrecht: Springer.

Ottestad, G. (2013). School leadership for ICT and teacher's use of digital tools. Nordic Journal of Digital Literacy, 1(2), 107-125.

Petersen, A-L. (2010). Pedagogiskt ledarskap i matematikundervisning. I S. Lagrosen, U. Lundh Snis \& E. Nehls (Eds.) Lärande i och för det nya arbetslivet. Lund: Studentlitteratur.

Petersen, A-L. (2012). Matematik behöver också en berättelse, om pedagogiskt ledarskap med fokus på elevens motivation. Acta Didactica Norge - Internasjonalt tidsskrift för fagdidaktisk forsknings-og utviklingsarbeid, 6(1), 1-17.

Petersen, A-L. (2013). Utvärdering av matematikprojekt i en kommuns fyra högstadieskolor år 2012. Rapport i Högskolan Västs rapportserie, Nr 2013:1. Available at: http://hv.divaportal.org/smash/get/diva2:600103/FULLTEXT01.pdf

Petersen, A-L. \& Bunting, L. (2012). Pedagogical use of laptops in one-to-one environment in a Swedish primary school. In Contemporary Educational Technology, 3(4), 249-264.

Pont, B., Nusche, D. \& Moorman, H. (2009). Förbättrat skolledarskap. OECD-rapport, Politik och Praktik, vol. 1. Stockholm: Skolverket.

Schibeci, R., MacCallum, J., Cumming-Potvin, W., Durrant, C., Kissane, B. \& Miller, E-J. (2008). Teachers' journeys towards critical use of ICT. Learning, Media and Technology. 33(4), 313-327.

Silverman, D. (2006). Interpreting Qualitative Data (3 ed.). London: Sage.

Skolverket (2011). Läroplan för grundskolan, förskoleklassen och fritidshemmet 2011. Stockholm: Skolverket.

Skolverket (2013). SIRIS database. Available at: http://siris.skolverket.se/siris/f?p=Siris:1:0 
Stedøy, I.M. (2006). Hur blir man en duktig matematiklärare? In J. Boesen; G. Emanuelsson. A. Wallby, \& K. Wallby (Eds.), Lära och undervisa matematik - Internationella perspektiv. Göteborg: Nationellt Centrum för Matematikutbildning.

Stuart, L.H., Mills, A.M. \& Remus, U. (2009): School leaders, ICT competence and championing innovations. Computers and Education, 53(3), 733-741.

Ärlestig, H. (2011). Vardagssamtal och rektors pedagogiska ledarskap. I J. Höög \& O. Johansson (Eds.), Struktur, kultur, ledarskap - Förutsättningar för framgångsrika skolor. Lund: Studentlitteratur

Correspondence: Ann-Louise Petersen, Department of Social and Behavioral Studies, Educational Science and Languages, University West, Trollhattan, Sweden 